\title{
CIMETIDINE PREMEDICATION IN ELECTIVE CAESAREAN SECTION
}

\author{
Brian G. Pickering, Richard J. Palahniuk and Maureen Cuniming
}

\section{ABSTRACT}

A single intramuscular injection of Cimetidine was compared to oral antacid premedication in 17 patients undergoing elective Caesarean section. Seven patients in the Cimetidine group and four in the antacid group had gastric volumes in excess of $50 \mathrm{ml}$ after induction of anaesthesia, while two patients in ench group had gastric $\mathrm{pH}$ less than $\mathbf{2 . 5}$ after induction. Cimetidine was as effective as antacid in raising gastric pH but neither was completely reliable. This study reconfirms the high gastric volumes in pregnant patients with the need for preventative measures against aspiration during the induction of anaesthesia.

ASPIRATION PNEUMONITIS CONTINUES to be a major concern in obstetrical anaesthesia,' with patients undergoing elective Caesarean section being as much at risk as those in labor. ${ }^{2}$ Among the measures currently recommended for preventing acid pneumonitis is the oral administration of antacids prior to Caesarean section or vaginal delivery. Cimetidine, an $\mathrm{H}^{+}$receptor histamine antagonist, has been shown to raise gastric $\mathrm{pH}$ in a number of medical conditions ${ }^{3}$ and has been investigated for use as a premedicant in elective surgical patients. ${ }^{4}$ Because Cimetidine offers several potential advantages over antacids for use in obstetrical patients, we compared the effects of Cimetidine and oral antacids on gastric volume and $\mathrm{pH}$ in patients coming to elective Caesarean section.

\section{METHODS}

This study was approved by the Human Ethics Committee of the University of Manitoba and Health Sciences Centre. Seventeen healthy patients scheduled to receive general anaesthesia for elective Caesarean section were studied. All patients were fully informed of the nature of the study and freely consented to take part. All patients were fasted for at least eight hours preoperatively and received no premedication

Brian G. Pickering, M.D.; Richard J. Palahniuk, M.D.; Maureen Cumming, R.N., B.Sc. Departments of Anaesthesia and Obstetrics and Gynaecology, University of Manitoba and Health Sciences Centre, Winnipeg. Manitoba

Address reprint requests to: Dr. R. Palahniuk, Department of Anesthesia, Health Sciences Centre General, Winnipeg, Manitoba, R3E 0Z3.

The authors are grateful to Drs. D. Bichl, M. Crocker and B. Ong. St. Boniface Hospital for assistance in performing the study.

Canad. Anaesth. Soc. J., vol. 27, no. 1, January 1980 other than the study drug. Patients were assigned to receive Cimetidine or antacid in a random fashion.

On the morning of surgery, the patient received either Cimetidine $300 \mathrm{mg}$ intramuscularly or antacid (Gelusil") $30 \mathrm{ml}$ orally, one hour before Caesarean section. All patients were maintained with a left tilt using a wedge under the right buttock. After the abdomen was prepared and draped, the patient was preoxygenated for two minutes following which anaesthesia was induced with d-tubocurare $3 \mathrm{mg}$ and thiopentone 3 $\mathrm{mg} \cdot \mathrm{kg}^{-1}$ intravenously. Cricoid pressure was applied and succinylcholine $100 \mathrm{mg}$ was administered intravenously to facilitate tracheal intubation. Positive pressure ventilation was avoided before the trachea was intubated. Anaesthesia was maintained with nitrous oxide $50 \mathrm{per}$ cent with oxygen and methoxyflurane 0.2 per cent. Muscle relaxation was obtained with dtubocurare as necessary and positive pressure ventilation was administered using an Ohio anaesthesia ventilator.

After delivery of the baby, a small bore gastric tube was passed through the mouth into the patient's stomach and $5 \mathrm{ml}$ of gastric fluid was removed for $\mathrm{pH}$ determination. Fifty $\mathrm{ml}$ of polyethylene glycol (PEG) one per cent was then injected into the stomach for determination of gastric volume by the dilution method described previously. ${ }^{5.6}$ The PEG was mixed with the gastric fluid by aspiration and reinjection several times. After mixing, the diluted gastric contents were removed as completely as possible.

Gastric $\mathrm{pH}$ was measured using an appropriately calibrated $\mathrm{pH}$ electrode. The PEG concentration in the gastric aspirate was determined by a turbidimetric method ${ }^{7}$ and the volume of fluid from the stomach diluting the PEG was calcu- 
TABLE

StUdy PATILNTS

\begin{tabular}{lcccccc}
\hline & \multicolumn{2}{c}{ Cimetidine $(n=9)$} & & \multicolumn{2}{c}{ Antacid $(n=8)$} \\
\cline { 2 - 3 } \cline { 6 - 7 } & Mean \pm S.D. & Range & & Mean \pm S.D. & Range \\
\hline Age (years) & 27 & $( \pm 2)$ & $17-43$ & & $27( \pm 2)$ & $21-34$ \\
Weight $(\mathrm{Kg})$ & 74 & $( \pm 2)$ & $67-81$ & & $75( \pm 5)$ & $56-104$ \\
Time fasted (hours) & $9.5( \pm 0.5)$ & $8-12$ & & $10( \pm 0.4)$ & $9-12$ \\
\hline
\end{tabular}

lated. Data from the two groups were compared using Student's t-test for unpaired data. $\mathrm{pH}$ data were averaged directly rather than converting to hydrogen ion concentrations.

\section{RESULTS}

All patients were classified as ASA I or II. One patient in the antacid group was a gestational diabetic receiving insulin. No other patient was receiving any medication. Nine patients received Cimetidine and eight were given antacids. The two groups were comparable in age, weight and fasting time (Table I).

Apgar scores in the two groups of infants were identical with only one baby having a five-minute score of six or less. This baby was delivered from a patient in the antacid group and had a fiveminute Apgar score of six. The mother was a gestational diabetic receiving insulin. The baby responded to resuscitative measures and was discharged in a healthy state. There was no evidence that Cimetidine caused any neonatal depression.

Gastric $\mathrm{pH}$ for the groups is shown in Table II In one patient in the cimetidine group it was impossible to get enough fluid to measure $\mathrm{pH}$. Two patients in each group had a gastric $\mathrm{pH}$ below 2.5 .

Gastric volumes in the two groups were quite variable, as shown in Table III. The difference in the volumes was not statistically significant. Seven patients in the Cimetidine group had volumes in excess of $50 \mathrm{ml}$, but three patients in the antacid group had volumes in excess of $100 \mathrm{ml}$, two of these being in excess of $200 \mathrm{ml}$.

If we accept that an adult would have to aspirate more than $25 \mathrm{ml}$ of gastric fluid with a $\mathrm{pH}$ less than 2.5 to produce fatal pneumonitis, ${ }^{8}$ two patients in each group would be classified as being at risk (Table IV).

\section{Discussion}

The use of the dilution method allows for a more accurate measurement of gastric volume than simple aspiration through a gastric tube. ${ }^{5}$ As
TABLE II

GASTRIC PH

\begin{tabular}{cccc}
\hline \hline & Mean & Range & Patients below 2.5 \\
\hline $\begin{array}{c}\text { Cimetidine } \\
(n=8)\end{array}$ & 5.03 & $1.9-6.7$ & 2 \\
$\begin{array}{c}\text { Antacid } \\
(n=8)\end{array}$ & 4.63 & $1.3-7.9$ & 2 \\
\hline
\end{tabular}

a result, the gastric volumes in the present study are substantially higher than those reported previously in patients undergoing Caesarean section."

Although oral antacids have been shown to be effective in raising the gastric $\mathrm{pH}$ above 2.5 in the majority of patients, "there are several potential disadvantages to their use in obstctrics. Gastric volume may be increased by the volume of antacid administered (usually $30 \mathrm{ml}$ ), while a few patients maintain a gastric $\mathrm{pH}$ below 2.5 despite the antacid. ${ }^{y}$ In addition, recent investigations ${ }^{10}$ and clinical reports" have suggested that aspirating antacid may cause as severe a pneumonitis as aspirating acid.

Cimetidine is reported to reduce gastric volume and to raise gastric $\mathrm{pH}$ by blocking gastric histamine receptors. ${ }^{3}$ It inhibits basal gastric acid secretion and antagonizes gastric acid stimulants.

This study found no significant advantage over antacids in raising gastric $\mathrm{pH}$ although the mean gastric volume in the Cimetidine group was less than that in the antacid group. The results suggest that neither Cimetidine nor antacid reliably prevent the danger of aspiration pneumonitis in elective Caesarean section patients. There were still two patients in each group who would be classified as being at risk of aspiration and it would not have been possible to distinguish these patients from the others by age, weight or hours fasted.

There is evidence that obese patients tend to have higher gastric volumes. ${ }^{12}$ In the current study, as well, the four patients with the highest gastric volumes measured all weighed over $75 \mathrm{~kg}$. It should be noted that we used a single in- 
PICKERING, et al.: CIMETIDINE IN CAESAREAN SECTION

TABLE III

Gastric Volume

\begin{tabular}{ccccc}
\hline \hline & Mean $(\mathrm{ml})( \pm$ S.D. $)$ & $<25 \mathrm{ml}$ & $\begin{array}{c}\text { Patient } \\
\text { distribution } \\
25-50 \mathrm{ml}\end{array}$ & $>50 \mathrm{ml}$ \\
\hline $\begin{array}{c}\text { Cimetidine } \\
(\mathrm{n}=9)\end{array}$ & $72( \pm 9)$ & 0 & 2 & 7 \\
$\begin{array}{c}\text { Antacid } \\
(\mathrm{n}=8)\end{array}$ & $104( \pm 43)$ & 1 & 3 & 4 \\
\hline
\end{tabular}

TABLE IV

PATIENTS AT RisK

\begin{tabular}{cccc}
\hline Patient & Group & $\mathrm{pH}$ & Volume(ml) \\
\hline 1 & Antacid & 1.4 & 26 \\
2 & Antacid & 1.3 & 60 \\
3 & Cimetidine & 2.0 & 40 \\
4 & Cimetidine & 1.9 & 77 \\
\hline
\end{tabular}

tramuscular dose of Cimetidine. Possibly a different regime of administration of this agent may prove to be more effective in reducing gastric volume and acidity. Perhaps oral administration on the day before operation combined with an intramuscular injection preoperatively may prove to be more effective.

In conclusion, neither Cimetidine nor antacids reliably raised gastric $\mathrm{pH}$ in all patients. All patients undergoing general anaesthesia for Caesarean section should continue to be regarded as at risk of developing aspiration pneumonitis and appropriate preventative measures should be taken to protect the airway. Cimetidine may be as effective as antacids in raising gastric $\mathrm{pH}$ and may replace antacids if the dangers of antacid aspiration are proved. It must also be remembered that histamine receptor antagonists may have central nervous system activity and further investigations are necessary before the routine use of Cimetidine in obstetrical anaesthesia can be recommended.

\section{REFERENCES}

1. Scotr, D.B. Mendelson's syndrome - editorial. Br. J. Anaesth. 50: 977 (1978).

2. Roberts, R.B. \& Shirley, M.A. Reducing the risk of acid aspiration during Cesarean section. Anes. Analg. 58: 859 (1974).

3. Code, C.F. Reflections on histamine, gastric secretion and the $\mathrm{H}_{2}$ receptor. N.E.J.M. 296: 1459 (1977).

4. Stoelting, R.K. Gastric fluid $\mathrm{pH}$ in patients receiving Cimetidine. Anesth. Analg. 57: 675 (1978).

5. Ong, B. Y, Palahniuk, R.J. \& Cumming, M. Gastric volume and $\mathrm{pH}$ in out-patients. Canad. Anaesth. Soc. J. 25: 36 (1978).

6. Blouw, R., Scatllff, J., Craig, D.B. \& Palahniuk, R.J. Gastric volume and $\mathrm{pH}$ in post partum patients. Anesthesiology 45: 474 (1976).

7. Malawer, S.J. \& Powell, D.W. An improved turbidimetric analysis of polyethylene glycol utilizing an emulsitier. Gastroenterology 53:250 (1967).

8. Teabiaut, J.R. Aspiration of gastric content: an experimental study. Am. J. Pathal. 28: 51 (1952).

9. TAYlor, E. \& PRYSE-Davies, J. Prophylactic use of antacids in the prevention of acid-pulmonaryaspiration syndrome. Lancet $1: 288$ (1966).

10. Gisss, C.P. Anlacid pulmonary aspiration. Abstracts of the Society of Obstetric Anesthesia and Perinatology meeting, Memphis (1978).

11. TAYLOR, $G$. Acid pulmonary aspiration syndrome after antacids. Br. J. Anaesth. 47: 615 (1975).

12. Vaughan, R.W., Bauer, S. \& Wise, L. Volume and $\mathrm{pH}$ of gastric juice in obese patients. Anesthesiology 43: 686(1975).

\section{RÉSUMÉ}

On a comparć la cimétidine administrée par voie intramusculaire à l'administration orale d'un antacide en prémédication chez 19 patientes accouchées par césarienne élective. Le volume du liquide gastrique a été supérieur à $50 \mathrm{ml}$ chez sept des neuf patientes ayant reçu une dose de cimétidine 30 minutes avant l'induction, alors que cette situation se retrouvait chez quatre des huit patientes ayant reçu un antacide. La cimétidine s'est avérée aussi efficace que l'antacide pour élever le $\mathrm{pH}$ du liquide gastrique, mais ni l'un ni l'autre n'était entièrement fiable. Cette étude reconfirme la présence de volumes liquidiens gastriques élevés chez les patientes enceintes et la nécessité d'utiliser des mesures pour prévenir l'aspiration au cours de l'induction de l'anesthésie. 